\title{
Biofertilizers with Organic Manures: A Better Strategy for Sustainable Productivity
}

\author{
Waqas Liaqat*, Muhammad Faheem Jan and Haseeb Ahmad \\ Department of Agronomy, University of Agriculture Peshawar, Pakistan
}

Submission: May 26, 2018; Published: August 07, 2018

*Corresponding author: Waqas Liaqat, Department of Agronomy, Faculty of Crop Production, University of Agriculture Peshawar, Pakistan; Email: waqasliaqat0043@gmail.com

\begin{abstract}
The application of microbial inoculants (biofertilizers) is a promising technology for future sustainable farming systems in view of rapidly decreasing phosphorus stocks and the need to more efficiently use available nitrogen (N). Various microbial taxa are currently used as biofertilizers, based on their capacity to access nutrients from fertilizers and soil stocks, to fix atmospheric nitrogen, to improve water uptake or to act as biocontrol agents. Bio-fertilizers with organic manures are the best modern tools and gift of our agricultural science as a replacement to our conventional fertilizers. Conventional fertilizers contain compost, household wastes and green manures which are not as effective as chemical fertilizers. So, farmers often try to use chemical fertilizers in the field for crop development. But obviously the chemical fertilizers are not environment friendly because of their chemical toxicity that can cause water, air and soil pollution and can spread cancer causing agents. Moreover, they may destroy the fertility of the soil in a long run. Scientists have developed the way of organic farming by use of "Bio-fertilizers" along with natural manures to prevent chemical pollution in farm lands. Bio-fertilizer contains microorganisms which promote the adequate supply of nutrients from organic manures to the host plants and ensure their proper development of growth and regulation in their physiology. Bio-fertilizer being essential components of organic farming play a vital role in maintaining long term soil fertility and sustainability. It can be concluded that application of bio-fertilizer with organic manure could improve production on sustainable basis.
\end{abstract}

Keywords: Biofertilizers, soil health, Eco-friendly, chemical fertilizers, Sustainable production Agricultural science; Soil stocks; Atmospheric nitrogen; Biocontrol agents; Farming; Nutrients; Pollution; Physiology; Crop development; Farmers; Pollution; Microorganisms; Soil fertility; Organ; Stimulating hormones; Plant nutrients

\section{Introduction}

One of the major crop productivity constraints in the third world is the unavailability of crop nutrients in appropriate amount and form [1]. Modern agricultural practices emphasize widespread use of fertilizers which certainly increased grain yield in many countries in the last six decades. However, long term use of chemical fertilizers also led to a decline in crop yield and soil fertility in the intensive cropping system [2]. It is evident that over fertilization increases concentration of several plant nutrients in surface as well as ground water, which creates a potential health hazard. This has in turn paved the way for integrated plant nutrient management.

The use of renewable resources and inputs is one the fundamental principles of sustainable agriculture that enables maximum crop productivity and minimal environmental risk. Therefore, an increased yield with reduced environmental risk requires new cultivation strategies including biological fertilizer $[3,4]$. Biofertilizer is a natural input that can be applied as a complement to, or as a substituent of chemical fertilizer in sustainable agriculture. Integrated use of biofertilizers with natural manures offer a low capital investment and eco-friendly route to boosting farm productivity $[5,6]$. Chemical fertilizers have outstandingly boosted crop yields about three decades back. However, yields are currently getting low or stagnated. Moreover, poor-resource holder farmers in developing countries apply little or no fertilizer due to high cost of procurement. Furthermore, applications of chemical fertilizers have caused ecological problems, degraded soil physico-chemical and biological qualities thereby led to poor crop yields.

In an effort to safe guard the environment, maintain soil as the store house and enhance sustainable crop yields, replacing chemical fertilizer is of paramount importance. In such scenario, bio-fertilizers (microbial inoculants) and organic manures could be recommended. Bio-fertilizer and organic manure are cheap and eco-friendly source of plant nutrients for sustainable crop production in low-input agriculture. Application of organic manures has positive effects on soil physical and biochemical properties. It lowers soil bulk density; increases water holding capacity, Cation Exchange Capacity (CEC), build up beneficial soil microbes, improve soil structure and enhance stable soil aggregates [7-9]. The role of biofertilizers alone or in 
combination with organic or inorganic fertilizers has recently gained recognition in sustainable crop production [10-12]. These microorganisms play crucial roles such as, producing plant growth stimulating hormones, nutrients cycling thereby enhancing plant nutrients availability and uptake, nitrogen fixation, improve plant health, drought resistance and reclaim degraded soil [13-16].

\section{Conclusion}

It can be concluded that application of biofertilizers in combination with organic manures could rehabilitate the degraded soil and reclamation of biodiversity for sustainable agriculture would be the ultimate result.

\section{References}

1. Hussain MZ, Rehman KN, Roohullah MA, Ahmed SR (2006) Micronutrients status of Bannubasen soils. Sarhad J Agric 22: 283- 285.

2. Dadhich SK, Somani LL, Shilpkar D (2011) Effect of integrated use of fertilizer P, FYM and biofertilizers on soil properties and productivity of soybean-wheat crop sequence. J Adv Dev Res 2: 42-46.

3. Kizilkaya R (2008) Yield response and nitrogen concentration of spring wheat to inoculated materials. J Adv Dev Res 4: 92-96.

4. Hegde DM, Dwived BS, Sudhakara SN (1999) Biofertilizers for cereal production in India-a review. Indian J agric Sci 69(2): 73-83.

5. Ebrahimpour F, Eidizadeh KH, Damghani AM (2011) Sustainable nutrient management in maize with integrated application of biological and chemical fertilizers. Int J Agric Sci 1: 423-426.

6. Thavaprakaash N, Velayudham K, Muthukumar VB (2005) Effect of crop geometry, intercropping systems and integrated nutrient management practices on productivity of baby corn (Zeamays L) based intercropping systems. J Agric Biol Sci 1: 295-302.

7. Doran J (1995) Building soil quality. In: Proceedings of 1995 Conservatin Workshop on Opportunities and Challenges in Sustainable
Agriculture.Red Deer, Alta., Canada. Alberta Conservation Tillage Society and Alberta Agriculture Conservation, Development Branch. pp. 151-158.

8. Drinkwater LE, Letourneau DK, Workneh F, Van BAHC, Shennan C (1995) Fundamental differences between conventional and organic tomato agroecosystems in California. Ecological Applications 5(4): 1098- 1112.

9. Stamatiadis S, Werner M, Buchanan M (1999) Field assessment of soil quality as affected by compost and fertilizer application in broccoli field (San Benito County, California). Applied Soil Ecology 12(3): 217 225 .

10. Kennedy IR, Choudhury ATMA, Kecskes ML (2004) Non-symbiotic bacterial diazotrophs in crop farming systems: can their potential for plant growth promotion be better exploited? Soil Biology and Biochemistry 36: 1229-1244.

11. Bloemberg GV, Wijfijes AH, Lamers GE, Stuurman N, Lugtenberg B (2000) Stimultaneous imaging of Pseudomonas flourescens WCS 3655 populations expressing three communities. Mol Plant Microbe Interact 13(11): 1170-1176.

12. Abdullahi R, Sheriff HH (2013) Effect of Arbuscular mycorrhizal fungi and chemical fertilizer on growth and shoot nutrients content of onion under field condition in Northern Sudan Savanna of Nigeria. Journal of Agriculture and Veterinary Science 3(5): 85-90.

13. Dobbelaere S, Croonenborghs A, Thys A, Ptacek D, Vanderleyden J, et al (2001) Response of agronomically important crops to inoculation with Azospirillum. Australian Journal of Plant Physiology 28(9): 871-879.

14. Hodge A, Campbell CD, Fitter AH (2001) An arbuscular mycorrhizal fungus accelerates decomposition and acquires nitrogen directly from organic mineral material. Nature 413: 297-299.

15. Bonfante P (2003) Plants, mycorrrhizal fungi, and endobacteria: a dialog among cells and genomes. Biol Bull 204(2): 215-220.

16. Vessey JK (2003) Plant growth promoting rhizobacteria as bioasfertilizers. Plant Science 255(2): 571-586.

Your next submission with Juniper Publishers will reach you the below assets

- Quality Editorial service

- Swift Peer Review

- Reprints availability

- E-prints Service

- Manuscript Podcast for convenient understanding

- Global attainment for your research

- Manuscript accessibility in different formats

( Pdf, E-pub, Full Text, Audio)

- Unceasing customer service

Track the below URL for one-step submission https://juniperpublishers.com/online-submission.php 